\section{JEWS AND HITTITES.}

\author{
BY FELIX VON LYSCHAN, BERLIN, GERMANY.
}

OUR modern Jews are generally believed to represent a pure and typical branch of the Semitic race, and even authors, who are well aware that we find mixed blood on the remotest and apparently most isolated islands of the Pacific, seem inclined to admit an exception for the Jews. It seems of interest, therefore, to study Jewish types, not only as to their general impression, but by measuring their heads and skulls and comparing them with other representatives of Semitic nations. The result has been a most striking one.

As Semitic races, or as others prefer to say, as branches of the Semitic race, we generally consider the Babylonians, the Assyrians, the Hebrews, the South Arabian Sabæans, the Phenicians, the Aramæans, the Abyssinians and the Bedouins of northern Arabia and of Mesopotamia. Now, the anatomical characteristics of these eight people, which all are, or have been, speaking typical Semitic languages, are most divergent; only the Bedouins, wnose language also is remarkable for its very archaic character, seem to form a homogeneous unity, with little mixture of strange elements; their modern physique is the same as we see it represented in the earliest Egyptian monuments, and also our earliest skulls of Phenicians seem identical with old and modern Bedouin skulls, so that we must consider the modern Bedouins as pure descendants of the old Semitic race. They have long, narrow heads, dark complexion, and a short, small and straight nose, which is in every respect the direct counterpart of what we are accustomed to call a "typical Jewish nose." But of our modern Jews nearly 50 per cent are brachycephalic, I per cent have fair complexion, and not more than 5 per cent correspond to what we have learned to be the real old Semitic type. Still more striking proportions we find, if we go to northern Syria, the land of the old Aramæans; there nearly all the heads are brachycephalic, with indices near to $9 \circ$; and these same brachycephalic elements we find everywhere in western Asia; we find them, more or less prominent, even with the modern Greeks, Armenians and Turks of Asia Minor, and specially the Armenians are most remarkable for the nearly complete uniformity of their types, for their dark complexion, for their extreme brachycephalism and for their large and hooked "Jewish" nose.

Such and other investigations lead us to the conviction that Syria and Asia Minor were in early times inhabited by a homogeneous and extreme brachycephalic race, of which modern Armenians are the nearly pure descendants, and which we find more or less mixed with strange elements, in many of the other races that now inhabit western Asia. This old brachycephalci race, which from its beginning was utterly distinct from any Semitic tribe and was in physical view the very counterpart of the Semites, can only be identified with the Hittites-the same Hittites mentioned as a Syrian tribe in the Bible, which had been a strong and formidable enemy to Ramses II., and were finally conquered by Assyrian Kings in long wars and fights, beginning earlier than the times of Assurnassirpal and ending probably only in those of Asarhaddon, as we read in the Assyrian annals from the ninth century to the seventh century, B. C.

Recent excavations, made for the Prussian government in Sendjirli, the old Sammâl, known in Assyrian texts as a Hittite residence in northern Syria, have brought to light a large series of old Hittite sculptures; the Armenian character of the men represented on the walls and in the royal palaces of this old town is most striking, and we cannot err if we consider the inhabitants of Sammâl as the direct ancestors of the modern Armenians, which still inhabit the neighborhood of the place, ill-treated in our times by Turks and Kourds and without any knowledge of their glorious history in ancient and mediæval times.

Hittite sculptures are often found connected with a very curious, heavy and bulky looking sort of hieroglyphic inscriptions, which are not yet finally deciphered, but are now getting more and more familiar to us, thanks to the investigations of A. H. Sayce, Peiser and Peter Jensen. We have no reason to doubt that these hieroglyphs were the only sort of writing known to the Hittites in early times. Now it is a curious fact that two inscriptions were found, written by native Kings, the one in the ninth, the other in the eighth century, B. C., both in good old Semitic alphabetical characters, resembling closely the famous inscription of Mesa, King of Moab, and in a language that might be called proto-Aramæan or proto-Hebrew, but which is anyhow old Semitic, and can well be compared with the language of some parts of the Bible. So the inscriptions I found in Sammâl ${ }^{1}$ show that already in the ninth century, B.C., Semitic influence was great in northern Syria, and we can now easily understand how Semitic writing and language soon became dominant among people of western Asia that were originally without a drop of Semitic blood; and then we understand also why most of our modern Jews have the Armenian type and not the Semitic-they are the descendants of an "Armenoïd" population that had only accepted Semitic writing and language in about rooo B. C.

This is a similar process to what we know for Asia Minor, where millions of the native population were by force converted to the Islâm, and, having accepted also the language of their Turkish conquerors, are now generally taken as real Turks, though their blood is nearly free from Turkish influence and though they can well be considered as the true and pure descendants of the old natives of their country.

But one thing still remains to explain in the habitus of the modern Jews; it is the fact of ir per cent of Jewish individuals with fair complexion and light eyes. All the various theories of recent mixture with Germanic elements would never sufficiently explain this curious fact; we are forced to look out for an old origin of the fair complexion of more than one-tenth of modern Jews, and we find it in the intercourse of the old native Syrians with the Amorites, the tall "sons of Enak" of the Bible, who were fair, with blue eyes, as old Egyptian painted monuments show us. We are not quite sure as to the real home of these fair Amorites, but they were probably a branch of the same fair race that once inhabited also the northwest coast of Africa, which has left there the megalithic monuments and is most certainly to be identified with the Tamcku of the old Egyptians, the white "people of the north" as their name explains. The Amorites would then be good fair Aryans, not in the linguistical meaning, as "IndoEuropeans," but in the strict sense of physical anthropology.

So we see in our modern Jews the descendants of three different races, the Hittites, the Aryan Amorites and the Semitic nomads, immigrated into Syria only in about the times of Abraham.

1 A usgrabungen in Sendschirli, Heft I. Berlin, Spemann, r893. 